\title{
The Transactivation Domains of the p53 Protein
}

\author{
Nitin Raj ${ }^{1}$ and Laura D. Attardi ${ }^{1,2}$ \\ ${ }^{1}$ Division of Radiation and Cancer Biology, Department of Radiation Oncology, Stanford University School \\ of Medicine, Stanford, California 94305 \\ ${ }^{2}$ Department of Genetics, Stanford University School of Medicine, Stanford, California 94305 \\ Correspondence: attardi@stanford.edu
}

The p53 tumor suppressor is a transcriptional activator, with discrete domains that participate in sequence-specific DNA binding, tetramerization, and transcriptional activation. Mutagenesis and reporter studies have delineated two distinct activation domains (TADs) and specific hydrophobic residues within these TADs that are critical for their function. Knockin mice expressing p53 mutants with alterations in either or both of the two TADs have revealed that TAD1 is critical for responses to acute DNA damage, whereas both TAD1 and TAD2 participate in tumor suppression. Biochemical and structural studies have identified factors that bind either or both TADs, including general transcription factors (GTFs), chromatin modifiers, and negative regulators, helping to elaborate a model through which p53 activates transcription. Posttranslational modifications (PTMs) of the p53 TADs through phosphorylation also regulate TAD activity. Together, these studies on p53 TADs provide great insight into how p53 serves as a tumor suppressor.

$\mathrm{O}^{\prime}$ ne of the best-characterized properties of the p53 tumor suppressor is its ability to activate gene transcription. Over the years, everincreasing numbers of direct p53-bound and activated genes have been identified, facilitated recently through genomic approaches. These genes have been shown to be involved in various p53 functions, including cell-cycle arrest/ senescence, apoptosis, regulating metabolism, DNA repair, and inhibiting cell migration and invasion (Vousden and Prives 2009; Bieging et al. 2014). Although we comprehend now that p53 transcriptional activation potential is fundamental for its function as a tumor suppressor, this understanding developed over a period of many years. In this review, we describe the studies that illuminated the role for p53 as a transcriptional activator, the importance of $\mathrm{p} 53$ transcriptional activation function in vivo, and the mechanisms through which p53 transcriptional activation domains act. Collectively, these studies have helped define the molecular underpinnings of $\mathrm{p} 53$ tumor suppressor function.

\section{p53 IS A TRANSCRIPTIONAL ACTIVATOR}

By 1989 , it was clear that $\mathrm{p} 53$ plays an important role in tumor suppression (Levine et al. 2004). However, the molecular mechanisms underlying p53's transformation suppression activity remained elusive. $\mathrm{p} 53$ was known to be nuclear and to have the capability to bind DNA through its highly conserved sequence-specific DNAbinding domain (DBD) (Dippold et al. 1981;

Editors: Guillermina Lozano and Arnold J. Levine

Additional Perspectives on The p53 Protein available at www.perspectivesinmedicine.org

Copyright (C) 2017 Cold Spring Harbor Laboratory Press; all rights reserved; doi: 10.1101/cshperspect.a026047

Cite this article as Cold Spring Harb Perspect Med 2017;7:a026047 
Bargonetti et al. 1991, 1993; Kern et al. 1991; Pavletich et al. 1993), but a significant clue that p53 might be a transcription factor came from analysis of the composition of the p53 amino acid sequence. In particular, the amino terminus of p53 is highly acidic ( $\sim 20 \%)$, a feature reminiscent of the acidic activation domains of other transcription factors such as Fos, GAL4, and the glucocorticoid receptor (Fig. 1) (Pennica et al. 1984; Ma and Ptashne 1987; Hollenberg and Evans 1988; Lech et al. 1988). In addition, p53 carries a proline-rich domain (PRD), another characteristic of transcriptional activation domains (TADs) such as in CTF/NF1 (Mermod et al. 1989). Of note, although the overall sequence of the p53 amino terminus is not highly conserved between species (Fig. 1A), the acidic character is conserved (Soussi and May 1996).

Direct evidence of p53 transactivation potential came first from experiments aimed at determining whether fusing either full-length or truncated p53 to the heterologous DBD of yeast GAL4 was sufficient to promote activation of a reporter carrying GAL4 binding sites. Indeed, fusion of either human or mouse p53 sequences to the GAL4 DBD, which itself has no transactivation potential, conferred transactivation activity in both yeast and mammalian cells (Fields and Jang 1990; O'Rourke et al. 1990; Raycroft et al. 1990, 1991; Hulboy and Lozano 1994). Initially, such experiments showed that the p53 amino-terminal 73 residues are sufficient to confer activation on the GAL4 DBD, to an extent similar to the potent herpes simplex virus VP16 TAD (Fields and Jang 1990). These experiments established that the p53 protein contains transactivating sequences, supporting the idea that it is a transcriptional activator. Experiments to further define the p53 TAD revealed that a fusion of GAL4 to $\mathrm{p} 53$ residues $1-42$ displayed activity comparable to that of GAL4 full-length p53, suggesting that p53 TAD activity is localized within amino acids 1-42 (Unger et al. 1992). Next, to correlate transcriptional activity with tumor suppression, GAL4 fusions to various p53 tumorderived mutants were generated. Interestingly, certain tumor-derived p53 mutants-known as conformation mutants because they disrupt p53 structure (mouse p53 ${ }^{\mathrm{A} 135 \mathrm{~V}}$, human $\mathrm{p} 53^{\mathrm{V} 143 \mathrm{~A}}, \mathrm{p} 53^{\mathrm{R} 175 \mathrm{H}}$ )-were unable to support reporter activation (Raycroft et al. 1990, 1991). In contrast, tumor-derived p53 mutants known as contact mutants (human p53 ${ }^{\mathrm{R} 273 \mathrm{H}}$, mouse $\mathrm{p} 53^{\mathrm{R} 245 \mathrm{~W}}$ ), which simply alter key residues required for $\mathrm{p} 53$ to interact with DNA but without affecting p53 structure, could still confer activation potential on the GAL4 DBD (Fields and Jang 1990; Raycroft et al. 1991; Unger et al. 1992). Collectively, these studies pinpointed regions of p53 with transactivation potential and suggested that the molecular mechanism accounting for p53-mediated tumor suppression is p53's ability to activate transcription (Fields and Jang 1990; O’Rourke et al. 1990; Raycroft et al. 1990, 1991; Unger et al. 1992; Hulboy and Lozano 1994). This work was complemented by subsequent studies showing that wild-type human and mouse p53 can bind defined DNA elements and activate transcription from specific promoters in in vitro transcription or transfection assays, whereas tumor-derived p53 mutants fail to do so (Farmer et al. 1992; Zambetti et al. 1992).

The generation of chimeras in which the p53 TAD was replaced with the heterologous VP16 TAD bolstered the notion that p53 is a transcriptional activator. Although deleting the p53 amino-terminal $\sim 79$ amino acids disrupts p53 function, reconstitution with an alternate TAD permits p53 function. In vitro assays showed that a p53-VP16 chimera can induce cell-cycle arrest or apoptosis in p53-deficient fibroblasts and suppress transformation (Reed et al. 1993; Pietenpol et al. 1994; Attardi et al. 1996). In addition, studies of cells from knockin mice expressing a p53-VP16 fusion showed that this chimera is capable of activating many classical p53 targets as well as cell-cycle arrest and senescence responses (Johnson et al. 2008). The fact that a different, well-defined TAD restored biological function to a p53 mutant lacking its own amino terminus strongly supported the idea that transactivation potential, rather than some other activity of the amino terminus, is critical for p53 biological function. 


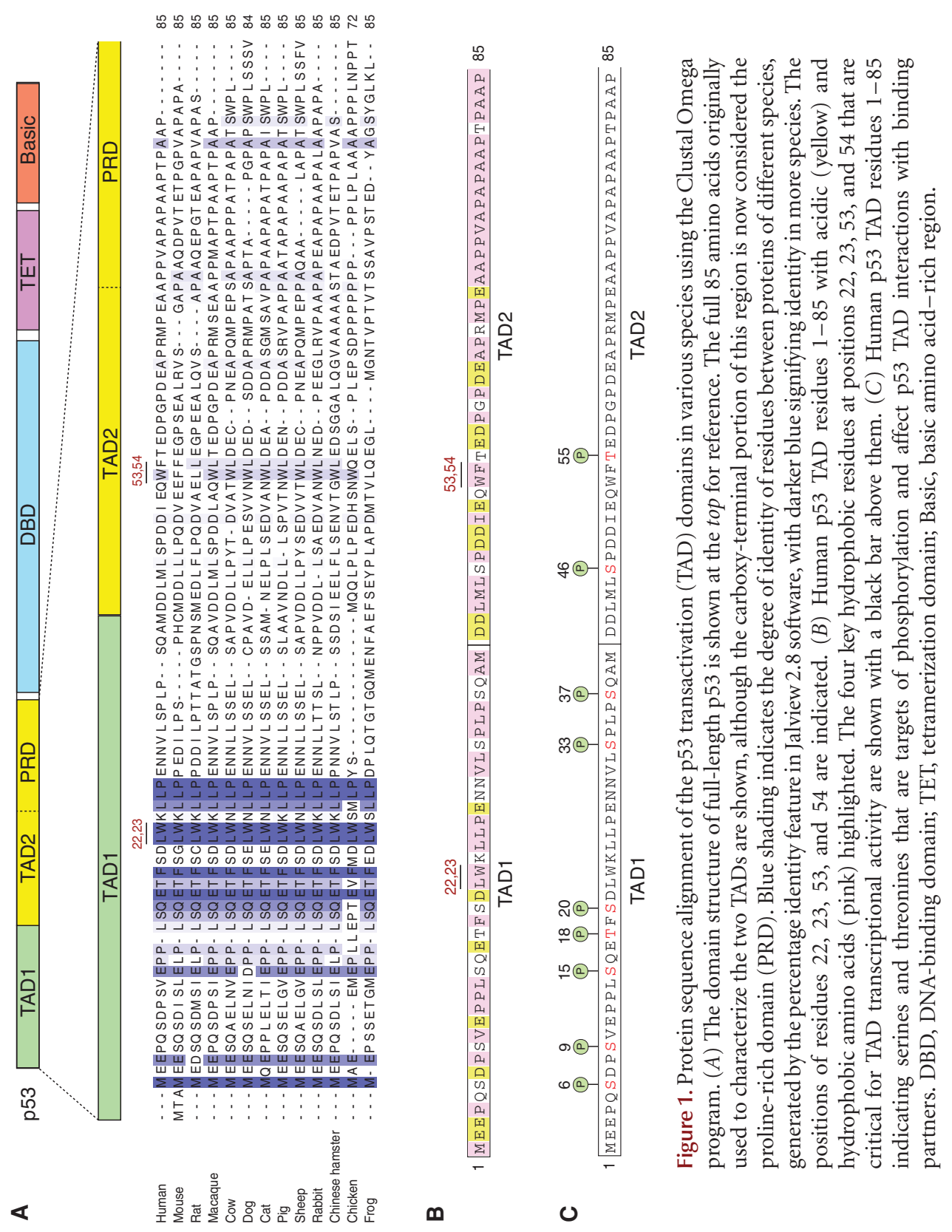




\section{SPECIFIC HYDROPHOBIC RESIDUES ARE CRITICAL FOR p53 TRANSACTIVATION DOMAIN FUNCTION}

Once the amino-terminal 42 amino acids were defined as sufficient for transcriptional activation, subsequent studies aimed to identify residues within this region critical for transactivation. Like the VP16 TAD, the p53 TAD has numerous acidic amino acids interspersed with bulky hydrophobic residues (Fig. 1B). Thus, a vast array of p53 TAD single, double, and multiple point mutants altering acidic and/or hydrophobic residues within the first 42 amino acids of p53 were analyzed for their transcriptional activity using reporter assays (Lin et al. 1994). Interestingly, these studies revealed that the acidic residues in the p53 amino terminus are not critical for $\mathrm{p} 53$ transactivation, although they do contribute to efficacy of transactivation. Instead, there are specific hydrophobic residues - primarily L22 and W23 of human p53-that are required for transactivation (but not for DNA binding). Notably, although each of the single-point mutations at codon 22 or 23 had a modest effect on transactivation, combined L22Q and W23S mutations resulted in loss of reporter activation. Similarly, mutagenesis of GAL4 DBD-p53(1-73) fusions showed that, although the acidic and proline residues contribute to efficient transactivation, the hydrophobic amino acids F19, L22, W23, L25, and L26 are the most crucial for activation (Chang et al. 1995). Interestingly, hydrophobic residues had been shown to be important for function of other transcription factors such as VP16, NTF-1, Sp1, and Gcn4 (Cress and Triezenberg 1991; Attardi and Tjian 1993; Gill et al. 1994; Drysdale et al. 1995). Collectively, these studies also advanced an explanation for the observation that $p 53$ mutations in cancer tend to occur in the DBD rather than the TAD. In contrast to the $\mathrm{DBD}$, which can be inactivated with one amino acid change, mutations in multiple TAD residues are required to significantly affect transactivation potential. There is, therefore, a much greater probability of sustaining one mutation in the DBD during cancer development than multiple alterations in the TAD (Lin et al. 1994).
Given that the human $\mathrm{p} 53^{\mathrm{L} 22 \mathrm{Q}, \mathrm{W} 23 \mathrm{~S}}$ mutant was found to be severely compromised for transactivation, it provided a useful tool to assess the role of p53 transcriptional activation for p53 biological function. In a variety of studies, the human $\mathrm{p} 53^{\mathrm{L} 22 \mathrm{Q}, \mathrm{W} 23 \mathrm{~S}}$ mutant and the analogous $\mathrm{p} 53^{\mathrm{L} 25 \mathrm{Q}, \mathrm{W} 26 \mathrm{~S}}$ mouse mutant were found to be totally defective in different p53 cellular functions, including DNA damage or oncogene-induced apoptosis or suppression of colony formation, leading to the conclusion that transcriptional activation potential is crucial for p53 to induce cellular responses (Sabbatini et al. 1995; Attardi et al. 1996; Chao et al. 2000). Interestingly, this mutant sometimes displayed activity in apoptosis or in transformation suppression in vitro, leading to the idea that transcriptional activation may not always be required for p53 function (Haupt et al. 1995; Sabbatini et al. 1995; Chen et al. 1996; Walker and Levine 1996; Zhu et al. 1998, 2000; Venot et al. 1999; Kokontis et al. 2001; Baptiste et al. 2002; Baptiste-Okoh et al. 2008). Alternatively, this context-dependent activity may relate instead to the fact that the $\mathrm{p} 53^{\mathrm{L} 22 \mathrm{Q}, \mathrm{W} 23 \mathrm{~S}}$ mutant possesses residual transcriptional activity on certain genes (Zhu et al. 1998, 2000; Venot et al. 1999; Brady et al. 2011). Together, these findings suggested the importance of transcriptional activation for p53 function in at least some contexts and foreshadowed a complexity to TAD function that was later clarified in mouse experiments in vivo (discussed below).

\section{p53 HAS TWO DISCRETE TRANSCRIPTIONAL ACTIVATION DOMAINS}

Shortly after these studies functionally defined the p53 TAD as between residues $1-42$, it was shown that p53 actually has two TADs within the amino terminus. This idea was originally proposed on the realization that there is a striking similarity between p53 residues $1-83$ and the activation domain of VP16 (residues 413490), which contains two independent TADs (Cress and Triezenberg 1991; Regier et al. 1993; Chang et al. 1995; Candau et al. 1997). The ability of p53 residues $40-83$ to serve as an independent TAD was therefore investigated. 
p53 amino acids $1-40$ and either $43-73$ or $40-$ 83 were fused to the GAL4 DBD, and these chimeras were assayed for their ability to activate reporters in yeast and mammalian cells. Indeed, GAL4-p53 (1-40), GAL4-p53 (43-73), and GAL4-p53 (40-83) have transactivation potential in reporter assays (Chang et al. 1995; Candau et al. 1997). Examination of the roles of the two TADs in the context of full-length p53, using p53 $3^{\Delta 1-39}$ and $553^{\Delta 34-78}$ mutants, showed that these two mutants have similar activities, albeit to a significantly reduced extent relative to wild-type p53 (Candau et al. 1997). These studies indicated that the two subdomains (henceforth referred to as TAD1 and TAD2) are both functional in the context of full-length protein, and, moreover, that the two domains act synergistically rather than additively. As with the L22 and W23 residues critical for TAD1 function, two consecutive hydrophobic residues in TAD2 (W53, F54), which are surrounded by acidic amino acids, were found to be critical for TAD2 activity. Together, these findings showed that there is a discrete second TAD in p53 that contributes significantly to p53 transcriptional activity and defined W53 and F54 as key residues for TAD2 function.

These studies were expanded by subsequent investigations of the biological activities of these mutants in vitro (Zhu et al. 1998, 2000; Venot et al. 1999). In one study, $\mathrm{p} 53^{\Delta \mathrm{N} 1-42}$ and $\mathrm{p} 53^{\mathrm{L} 22 \mathrm{Q}, \mathrm{W} 23 \mathrm{~S}}$, but not $\mathrm{p} 53^{\Delta \mathrm{N} 1-63}$, induced apoptosis, suggesting further the existence of a second TAD between residues 43 and 63 (Zhu et al. $1998,2000)$. In another study, p53 $3^{\mathrm{L} 22 \mathrm{Q}, \mathrm{W} 23 \mathrm{~S}}$ retained the ability to suppress colony growth and trigger apoptosis, consistent with residual transactivation function on some genes (Venot et al. 1999). To determine whether p53 TAD2 accounted for biological activities in these studies,

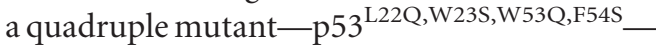
as well as a $\mathrm{p} 53^{\mathrm{W} 53 \mathrm{Q}, \mathrm{F} 54 \mathrm{~S}}$ mutant were generated and evaluated functionally in several p53-based assays (Venot et al. 1999). p53 ${ }^{\mathrm{W} 53 \mathrm{Q}, \mathrm{F} 54 \mathrm{~S}}$ activated reporters to an extent intermediate between wild-type p53 and the p53 ${ }^{\mathrm{L} 22 \mathrm{Q}, \mathrm{W} 23 \mathrm{~S}}$ mutant, while $\mathrm{p} 53^{\mathrm{L} 22 \mathrm{Q}, \mathrm{W} 23 \mathrm{~S}, \mathrm{~W} 53 \mathrm{Q}, \mathrm{F} 54 \mathrm{~S}}$ failed to transactivate reporters. $\mathrm{p} 53^{\mathrm{L} 22 \mathrm{Q}, \mathrm{W} 23 \mathrm{~S}}$ and $\mathrm{p} 53^{\mathrm{W} 53 \mathrm{Q}, \mathrm{F} 54 \mathrm{~S}}$ each induced apoptosis and colony suppres- sion almost equivalently but not as well as wild-type p53. p53 $3^{\Delta \mathrm{N} 1-42+\mathrm{W} 53 \mathrm{Q}, \mathrm{F} 54 \mathrm{~S}}$ and $\mathrm{p} 53^{\mathrm{L} 22 \mathrm{Q}, \mathrm{W} 23 \mathrm{~S}, \mathrm{~W} 53 \mathrm{Q}, \mathrm{F} 54 \mathrm{~S}}$ were both unable to induce cell-cycle arrest, apoptosis, colony suppression, or target gene expression, bolstering the functional significance of residues 53 and 54 and the second TAD (Zhu et al. 1998; Venot et al. 1999). Notably, the demonstration that abolishing transcriptional activity through mutation of both TADs incapacitates p53 biological activity underscores the importance of transcriptional activation activity for p53 function.

\section{FUNCTIONAL ANALYSIS OF p53 TRANSACTIVATION DOMAINS IN VIVO}

To definitively understand the role of the two p53 TADs for p53 function in vivo, a panel of p53 TAD mutant knockin mouse strains was generated (Johnson et al. 2005; Brady et al. 2011). Mutations previously characterized in in vitro assays (Candau et al. 1997; Zhu et al. 1998, 2000; Venot et al. 1999) were introduced into the first (L25Q, W26S), second (F53Q, F54S), or both TADs (L25Q, W26S, F53Q, F54S). A major strength of this approach is that mutants are expressed under the control of the $p 53$ promoter, hence with the proper spatial and temporal expression profile. In addition, a lox-stop-lox element was introduced upstream of the p53 coding sequence to allow conditional activation of the mutant alleles by Cre recombinase expression. Analysis of the p53 ${ }^{\mathrm{L} 25 \mathrm{Q}, \mathrm{W} 26 \mathrm{~S}}$ mutant, both in cells derived from the mice and in mice, provided an additional perspective on why this mutant showed variable activity in vitro. Specifically, this mutant displayed selective transactivation activity both by genome-wide expression profiling and by analysis of expression of individual genes. For example, $\mathrm{p} 53^{\mathrm{L} 25 \mathrm{Q}, \mathrm{W} 26 \mathrm{~S}}$ is severely compromised in activating $p 21$, Noxa, and Puma but not Bax or a number of novel p53-regulated genes (Fig. 2) (Johnson et al. 2005; Brady et al. 2011). Moreover, $\mathrm{p} 53^{\mathrm{L} 25 \mathrm{Q}, \mathrm{W} 26 \mathrm{~S}}$ is unable to mount responses to acute DNA damage, either cell-cycle arrest in DNA-damaging agent-treated mouse fibroblasts or apoptosis in radiosensitive tissues in vivo on irradiation, suggesting that full tran- 
N. Raj and L.D. Attardi

A

\begin{tabular}{|c|c|c|c|c|}
\hline \multicolumn{2}{|c|}{ Transactivation } & \multirow{2}{*}{$\begin{array}{c}\begin{array}{c}\text { Acute DNA } \\
\text { damage } \\
\text { responses }\end{array} \\
+ \\
+\end{array}$} & \multirow{2}{*}{$\begin{array}{c}\begin{array}{c}\text { Tumor } \\
\text { suppression }\end{array} \\
+\end{array}$} & \multirow{2}{*}{$\begin{array}{c}\begin{array}{c}\text { Embryonic } \\
\text { lethality }\end{array} \\
-\end{array}$} \\
\hline p53 WT & + & & & \\
\hline p53 $3^{\mathrm{L} 25 \mathrm{Q}, \mathrm{w} 26 \mathrm{~S}}$ & $+/-$ & - & + & + \\
\hline $\mathrm{p} 53^{\mathrm{F} 53 \mathrm{Q}, \mathrm{F} 54 \mathrm{~S}}$ & + & + & + & - \\
\hline$p 53^{\mathrm{L} 25 \mathrm{Q}, \mathrm{W} 26 \mathrm{~S}, \mathrm{~F} 53 \mathrm{Q}, \mathrm{F} 54 \mathrm{~S}}$ & - & - & - & - \\
\hline
\end{tabular}

B

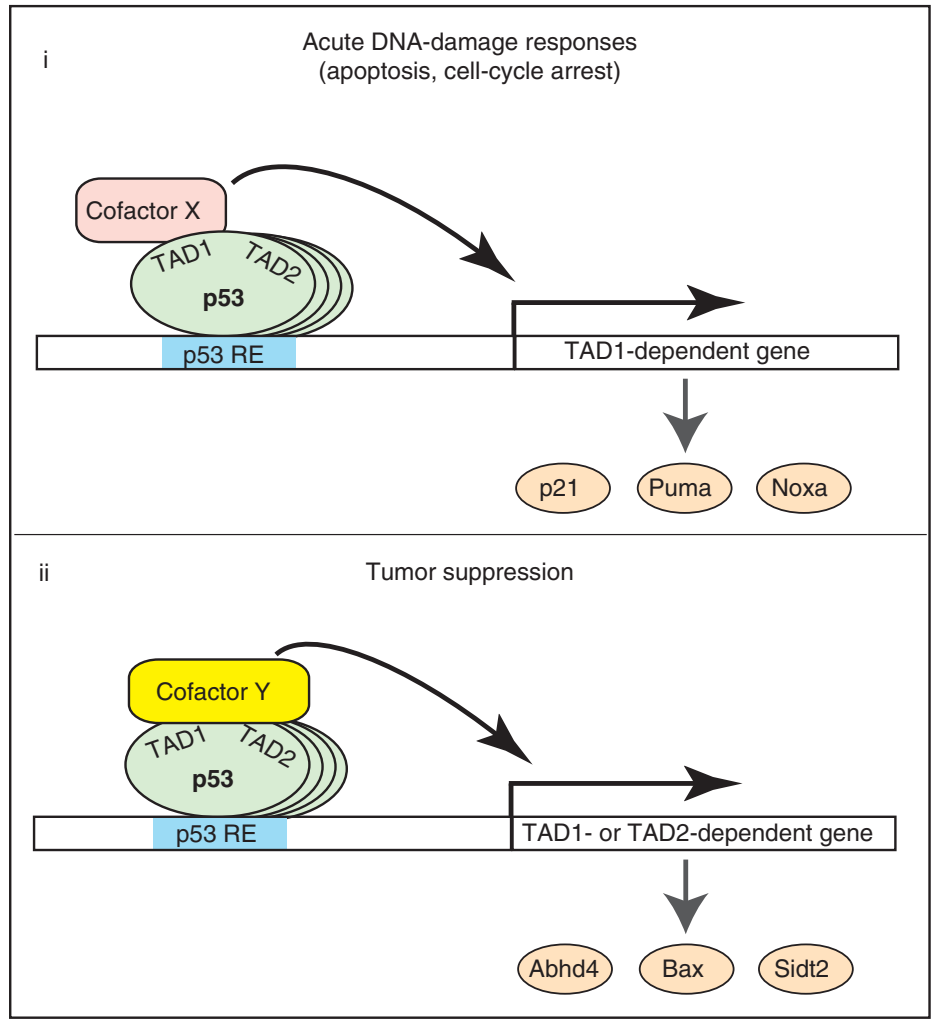

Figure 2. Molecular models for p53 transactivation at different target genes based on p53 TAD mutant phenotypes. (A) Table summarizing properties of the indicated mouse p53 TAD mutants relative to wild-type p53. + indicates wild-type activity and - indicates lack of activity. + / - indicates selective transactivation, with severely compromised activation of most p53 target genes and intact transactivation of a small subset of p53 target genes. Acute DNA-damage responses encompass cell-cycle arrest and apoptosis in response to DNA damage. Embryonic lethality is in the context of one mutant allele and one p53 null allele. (B) Models for p53 action in responses to acute DNA damage versus tumor suppression. p53 TAD1 activity is required for robust transactivation of canonical p53 target genes, such as p21, Puma, and Noxa, that mediate p53 DNA-damage responses, including apoptosis and cell-cycle arrest (i). In contrast, TAD1 is dispensable for activation of some p53 target genes, such as Abhd4, Bax, and Sidt2, and for tumor suppression, as either TAD1 or TAD2 suffices for these responses (ii). In model $i$, p53 uses TAD1 to interact with cofactor X to drive expression of TAD1-dependent genes. In model $i i$, p53 uses both TADs to interact with cofactor $\mathrm{Y}$ to activate genes associated with tumor suppression, as based on the observation that mutation of either TAD alone does not compromise expression of these genes. 
scriptional activity is critical for the ability to drive responses to acute DNA damage. In contrast, the $\mathrm{p} 53^{\mathrm{L} 25 \mathrm{Q}, \mathrm{W} 26 \mathrm{~S}}$ mutant can induce apoptosis in response to nongenotoxic stresses such as hypoxia and serum starvation (Johnson et al. 2005). Additionally, this mutant is completely competent to respond to oncogenic signals, inducing senescence in HRasV12-expressing MEFs and suppressing cancers of different types in vivo, including non-small-cell lung cancer, $\mathrm{T}$ and B-cell lymphoma, and medulloblastoma (Brady et al. 2011; Jiang et al. 2011). These findings suggest that selective transcriptional activation suffices for p53-mediated tumor suppression. This notion is consistent with the lack of tumor suppressor activity of a $\mathrm{p} 53^{\mathrm{L} 25 \mathrm{Q}, \mathrm{W} 26 \mathrm{~S}} \mathrm{mu}-$ tant also carrying the DBD mutation $\mathrm{A} 135 \mathrm{~V}$, which perturbs targeting to $\mathrm{p} 53$ consensus sites (Jimenez et al. 2000; Nister et al. 2005). However, based on these original studies, it remained possible that transcriptional activation-independent activities of p53 account for p53 function in these contexts and, therefore, it was necessary to investigate the biological activity of the transactivation-dead $\mathrm{p} 53^{\mathrm{L} 25 \mathrm{Q}, \mathrm{W} 26 \mathrm{~S}, \mathrm{F5} 3 \mathrm{Q}, \mathrm{F5} 4 \mathrm{~S}}$ mutant. Although the $\mathrm{p} 53^{\mathrm{F} 53 \mathrm{Q}, \mathrm{F} 54 \mathrm{~S}}$ mutant showed no apparent compromise in transactivation or biological activities, the p53 ${ }^{\mathrm{L} 25 \mathrm{Q}, \mathrm{W} 26 \mathrm{~S}, \mathrm{~F} 53 \mathrm{Q}, \mathrm{F} 54 \mathrm{~S}}$ mutant failed to show activity in activating target genes, inducing responses to DNA damage, or suppressing B- and T-cell lymphomas and lung cancer (Brady et al. 2011; Jiang et al. 2011). These observations thus show that transcriptional activity is crucial for p53 biological function and highlight the importance of TAD2 for tumor suppression, at least in the context of TAD1 mutation.

The study of these mutant mouse strains has also shed light on p53 function in embryonic development. Unrestrained p53 function during development, as occurs with ablation of either of the two p53 negative regulators, Mdm2 or MdmX, results in embryonic lethality, at E5.5 and E7.5-11.5, respectively, because of inappropriate p53-driven apoptosis or cell-cycle arrest in embryos (Jones et al. 1995; Montes de Oca Luna et al. 1995; de Rozieres et al. 2000; Parant et al. 2001; Finch et al. 2002; Migliorini et al. 2002). To assess whether the deleterious effects of unbridled p53 activity during development relies on p53 transcriptional activation function, the TAD mutants were expressed during development. Importantly, mutation at the residues 25;26 disrupt p53 interaction with Mdm2 (Lin et al. 1994); therefore, the proteins carrying these amino acid alterations are stabilized and can be studied as if in a Mdm2 nullizygous background. Each $p 53^{L S L-m /+}$ mouse strain-where $m$ denotes any mutant-was crossed to mice carrying a CMV-Cre transgene, to allow ubiquitous expression of the particular mutant throughout the developing organism, along with wild-type p53. Interestingly, although the expression of $\mathrm{p} 53^{\mathrm{F} 53 \mathrm{Q}, \mathrm{F} 54 \mathrm{~S}}$ failed to affect development, expression of p53 $3^{\mathrm{L} 25 \mathrm{Q}, \mathrm{W} 26 \mathrm{~S}}$ induced embryonic lethality at $\sim$ E10.5 associated with neural tube closure defects (Johnson et al. 2005; Van Nostrand et al. 2014). Moreover, expression of $\mathrm{p} 53^{\mathrm{L} 25 \mathrm{Q}, \mathrm{W} 26 \mathrm{~S}, \mathrm{~F} 53 \mathrm{Q}, \mathrm{F5} 4 \mathrm{~S}}$ provoked lethality at $\sim$ E13.5, associated with a host of phenotypes, including coloboma (fissure in the retina), heart outflow tract defects, and aberrant outer ear and semicircular canal formation (Van Nostrand et al. 2014). Notably, these phenotypes were not observed in $p 53^{L S L-25,26,53,54 /} ; C M V$-Cre embryos, which develop into viable adults (although they ultimately succumb prematurely to cancer), suggest that there is a genetic interaction between $\mathrm{p} 53^{\mathrm{L} 25 \mathrm{Q}, \mathrm{W} 26 \mathrm{~S}, \mathrm{F5} 3 \mathrm{Q}, \mathrm{F} 54 \mathrm{~S}}$ and wild-type p53 that leads to the specific constellation of phenotypes observed. Furthermore, the viability of $p 53^{L S L-25,26,53,54 /-}$ mice indicates that transcriptional activation is critical for p53 to induce developmental defects. Intriguingly, the specific spectrum of phenotypes resembles those seen in a human syndrome known as CHARGE (coloboma heart defects atresia of the chonae retarded growth genitourinary tract defects and ear defects), which is associated with mutations in the Chd7 chromatin remodeler (Jongmans et al. 2006). Although the transactivation-dead p53 $3^{\mathrm{L} 25 \mathrm{Q}, \mathrm{W} 26 \mathrm{~S}, \mathrm{~F} 53 \mathrm{Q}, \mathrm{F} 54 \mathrm{~S}}$ mutant does not itself compromise development, the $\mathrm{p} 53^{\mathrm{L} 25 \mathrm{Q}, \mathrm{W} 26 \mathrm{~S}}$ mutant retains adequate function through TAD2 to cause lethality even in the context of one $p 53$ null allele, again underscoring the functionality of the second TAD. Collectively, these 
studies revealed a complexity to TAD function in vivo, with a role for TAD1 in responses to acute DNA damage and for both TADs in tumor suppression and developmental phenotypes (Fig. 2). A mechanistic understanding of the basis for these intriguing observations necessitates a detailed biochemical analysis of interacting partners, which we will discuss next.

\section{p53 TRANSACTIVATION-DOMAIN- INTERACTING PROTEINS}

Transcriptional activators stimulate gene transcription through a precisely orchestrated series of steps. After binding to specific DNA sites via their sequence-specific DBDs, transcriptional activators must then open the adjacent chromatin and recruit the transcriptional machinery to promote RNA synthesis. Typically, through their TADs, transcriptional activators attract a variety of proteins engaged in different steps of transcription, including histone modification, chromatin remodeling, and transcriptional initiation and elongation (Lemon and Tjian 2000). Accordingly, the amino-terminal p53 TADs interact with proteins involved in different steps of transcription, as outlined below (Table 1). Moreover, the p53 TADs are important for interactions with the p53 inhibitors $\mathrm{Mdm} 2$, $\mathrm{MdmX}$, and E1B, providing another level of transcriptional regulation.

\section{p53 TADs Enhance Recruitment and Activity} of General Transcription Factors

Transcription of eukaryotic genes requires the assembly of the general transcription factors (GTFs) and Pol II on gene promoters to form the so-called preinitiation complex (PIC) (Murakami et al. 2013). The first GTF to nucleate PIC formation is transcription factor IID (TFIID, comprising the TATA-box-binding protein [TBP] and multiple TBP-associated factors [TAFs]), which binds to the TATA box, a promoter element important for directing proper transcription initiation (Conaway and Conaway 1993). p53 can interact directly with different components of the TFIID complex to promote transcriptional initiation (Seto et al. 1992; Chen et al. 1993b; Liu et al. 1993; Truant et al. 1993; Lin et al. 1994; Chang et al. 1995; Horikoshi et al. 1995; Lu and Levine 1995; Thut et al. 1995). The wild-type human p53 TADs (residues 1-73) interact with TBP via conserved hydrophobic residues, as F19R, L22R;W23S, or L25R;L26S mutations significantly decrease TBP binding (Chang et al. 1995). Interestingly, L22Q;W23S mutations in the context of fulllength p53 do not impair interaction with TBP (Lin et al. 1994), suggesting that TBP might bind to other p53 domains beyond TAD1 such as the carboxyl terminus (Horikoshi et al. 1995). p53 TAD1 also interacts with two additional subunits of the TFIID complex, TAF6 and TAF9 (formerly known as TAF70 and TAF32, respectively), and these interactions are abolished by the L22A;W23A, L22Q;W23S, or L14Q;F19S mutations in TAD1 (Lu and Levine 1995; Thut et al. 1995). The correlation between the ability of the p53 TADs to interact with TFIID components and to activate transcription suggests that these interactions are important for transcriptional activity. Beyond TFIID, the p53 TADs also interact with the GTF transcription factor IIH (TFIIH) (Xiao et al. 1994). Human p53 TAD residues $20-73$ are sufficient for binding to the pleckstrin homology $(\mathrm{PH})$ domains of the $\mathrm{p} 62$ and $\mathrm{Tfb} 1$ subunits of the human and yeast TFIIH complexes, respectively (Di Lello et al. 2006). In contrast, TFIIH does not bind to p53 TAD1 (residues 1-40), suggesting that it interacts specifically with TAD2, a notion borne out by NMR structural studies of the Tfb1/p53 complex. Together, these studies suggest that TAD1 and TAD2 cooperate to recruit both TFIID and TFIIH to promoters to stimulate transcriptional initiation.

In addition to contacting the general transcription machinery directly, p53 communicates with the GTFs via the Mediator (also known as TRAP [thyroid hormone receptor-associated protein] or SMCC [SRB- and MED-containing coactivator complex]), an evolutionarily conserved, multisubunit complex that acts as a central scaffold in the PIC, transmitting signals from transcriptional activators directly to Pol II to enhance transcriptional initiation (Conaway and Conaway 2013). Medi- 
Transactivation Domains of the p53 Protein
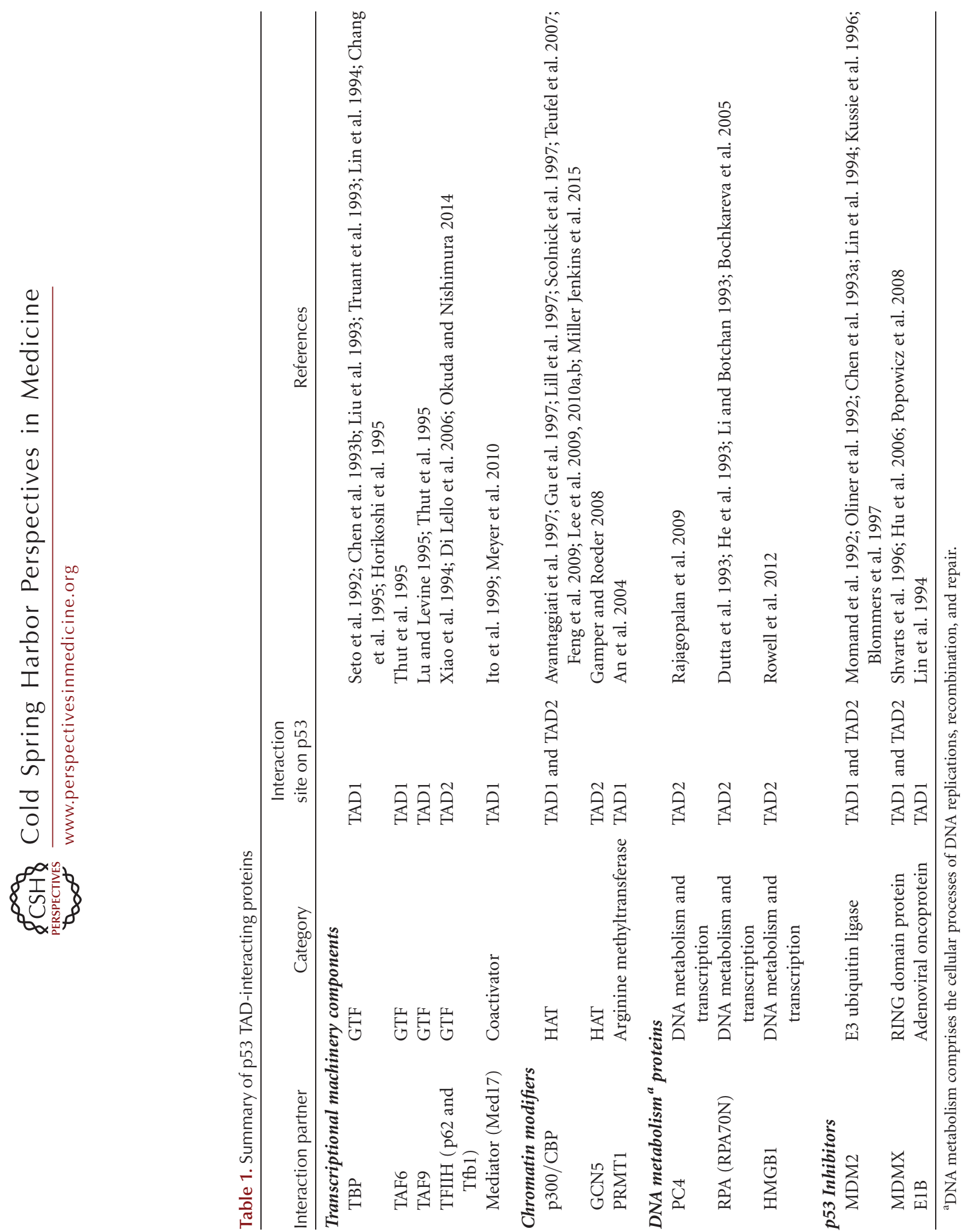
ator subunits Med1 and Med 17 (originally known as TRAP220 and TRAP80, respectively) interact directly with wild-type p53, although only Med17 binds the isolated p53 TAD1 while Med1 binds to the p53 carboxy-terminal domain (Ito et al. 1999). Accordingly, the p53 ${ }^{\mathrm{L} 22 \mathrm{Q} ; \mathrm{W} 23 \mathrm{~S}}$ mutant can interact with Med1 but not with Med17, suggesting that p53 may recruit Mediator components via multiple points of interaction. Electron microscopy analysis showed that p53 TAD binding to Med17 triggers a dramatic shift in Med17 architecture, such that a large "pocket" opens up in Med17 at a site where Pol II is known to bind, leading to the model that this p53-induced structural shift in Med17 promotes Pol II transitioning to its productive elongation state (Meyer et al. 2010). These studies collectively thus helped establish a mechanism for p53-mediated transactivation in which the p53 TADs both directly and indirectly-through Mediator-recruit and activate core transcription machinery.

\section{p53 TADs Interact with Chromatin Modifiers}

Before p53 can recruit and activate GTFs, p53 interacts with chromatin-modifying proteins to open chromatin. The best-studied p53-interactors in this category are CREB-binding protein (CBP) and p300, histone acetyltransferase (HAT) paralogs important for p53-mediated transactivation (Avantaggiati et al. 1997; Gu et al. 1997; Lill et al. 1997; Scolnick et al. 1997). Initial studies showed that p300 and CBP stably complex with p53 and enhance p53 transactivation, suggesting that these proteins function as coactivators of $\mathrm{p} 53$. Beyond promoting chromatin opening by histone acetylation, p300/CBP binding to p53 TADs, such as in response to DNA damage, also stabilizes p53 by inducing acetylation of $\mathrm{p} 53$ at multiple sites in the carboxyl terminus, thereby preventing p53 ubiquitylation at these sites and consequent degradation (Rodriguez et al. 2000; Li et al. 2002; Brooks and Gu 2003).

p53 interacts with multiple conserved domains in p300 and CBP, including the KIX (CREB and Myb interaction domain), TAZ1/ $\mathrm{CH} 1$ and TAZ2/CH3 (transcriptional adaptor zinc-binding domain; cysteine-histidine rich), and IBiD (interferon response-binding domain; also known as nuclear receptor coactivatorbinding domain or NCBD) domains (Teufel et al. 2007). p53 TAD1 and TAD2 (amino acids 1-57) can synergistically interact with each domain of p300/CBP. Because p53 binds DNA as a tetramer with four available TAD1/TAD2 domains, the p53 TADs may make multivalent interactions with the four domains of p300/ CBP. Deletion of either TAD or mutation of L22Q;W23S or W53Q;F54S in the context of full-length p53 diminishes binding to CBP (Gu et al. 1997; Scolnick et al. 1997). Moreover, analysis of p53 residues $1-57$ revealed that the L22Q;W23S;W53Q;F54S mutations-which render p53 transactivation-dead-abrogates interactions with each of the four p300 domains (Teufel et al. 2007). Thus, loss of p300/CBP binding may explain the inactivity of the p53 ${ }^{\mathrm{L} 25 \mathrm{Q}, \mathrm{W} 26 \mathrm{~S}, \mathrm{~F} 53 \mathrm{Q}, \mathrm{F} 54 \mathrm{~S}}$ mutant in transactivation and biological function.

p53 TADs are also known to interact with various other chromatin-modifying enzymes. For example, two components of the human STAGA HAT complex-GCN5 and TAF9-directly interact with p53 TAD residues $1-73$ (Gamper and Roeder 2008). This interaction is required for loading of STAGA onto promoters to allow chromatin opening and p53-mediated transactivation. Mutation of either p53 TAD1 (L22Q;W23S) or TAD2 (W53Q;F54S) results in weakened STAGA binding to p53, whereas the L22Q;W23S;W53Q;F54S mutations affect the interaction more severely, supporting the idea that STAGA binding may be key for transactivation. These findings are consistent with earlier observations showing that p53 TADs require GCN5 HAT activity for transcriptional activation in yeast (Candau et al. 1997). p53 also regulates chromatin state by binding the PRMT1 arginine methyltransferase, via residues $1-43$, thereby promoting p300/CBP acetyltransferase mediated to enhance p53 target gene expression (An et al. 2004). Together, these studies show that p53 TADs directly recruit various specialized regulators to alter the chromatin landscapes in the vicinity of p53 target promoters, preparing for PIC nucleation. 
p53 Transactivation Domain Interactions with Negative Regulators

Beyond interacting with transcriptional machinery components, the p53 TADs bind several negative regulators of $\mathrm{p} 53$ that suppress its ability to activate transcription. For example, the p53 amino-terminal 52 amino acids interact with the Mdm2 (Murine double minute) protein, an E3 ubiquitin ligase that inhibits p53mediated transactivation both by binding and concealing the $\mathrm{p} 53 \mathrm{TAD}$ and by targeting p53 for ubiquitin-mediated proteolysis (Momand et al. 1992; Oliner et al. 1992; Chen et al. 1993a; Haupt et al. 1997; Honda et al. 1997; Kubbutat et al. 1997). Mdm2 directs p53 degradation via the proteasome by ubiquitylating multiple lysines in the carboxyl terminus of p53 (Rodriguez et al. 2000). Mutagenesis studies defined F19, W23, and L26 as key human p53 residues for interacting with $\mathrm{Mdm} 2$ and its human ortholog, HDM2, a notion supported later by structural studies (Lin et al. 1994; Kussie et al. 1996; Blommers et al. 1997) (see below). Interestingly, the phenomenon of a TAD overlapping a degron has been observed in a host of transcriptional activators, including $\mathrm{Myc}, \beta$-catenin, c-Jun, and E2F (Salghetti et al. 2000, 2001; Kim et al. 2003; Lipford and Deshaies 2003; Muratani and Tansey 2003). Ubiquitinmediated proteolysis can actually enhance the activity of transactivators, as exemplified by the observation that p53 and components of the proteasome interact and are recruited to the $p 21$ promoter to promote transcription (Zhu et al. 2007). Although the rationale for coupling activator destruction and transcriptional activation is not completely clear, it has been proposed that proteolytic destruction of the activator may allow replacement of "spent" activators with new ones (Geng et al. 2012).

MdmX (also known an Mdm4) and its human counterpart HDMX are also negative regulators of p53 (Shvarts et al. 1996). Unlike Mdm2, MdmX inhibits p53-mediated transactivation but does not directly affect p53 protein stability, as it lacks E3 ubiquitin ligase activity. Similarly to Mdm2, MdmX directly binds p53 TAD residues $1-52$, and mutations of
L22Q;W23S abolish this interaction ( $\mathrm{Hu}$ et al. 2006). By binding to p53, Mdm2 and MdmX can inhibit p53 acetylation by coactivators such as p300/CBP, thereby dampening p53 transcriptional activity (Kobet et al. 2000; Sabbatini and McCormick 2002). Another well-established negative regulator of p53 is adenoviral E1B 55-kDa protein, which binds the amino-terminal 123 amino acids of $\mathrm{p} 53$, thereby masking the TADs and promoting oncogenic transformation (Lin et al. 1994). Interestingly, hydrophobic residues W23, K24, and P27 in p53 are critical for the interaction with E1B, suggesting that E1B may also inhibit p53 TADs by blocking sites for critical coactivators.

\section{STRUCTURAL ANALYSES OF THE p53 TRANSCRIPTIONAL ACTIVATION DOMAINS}

To gain a deeper understanding of the function of p53 TADs, a variety of structural biology approaches were used to examine the TADs in isolation and complexed with different interacting proteins. As with other transcription factors, it was expected that the p53 TADs in isolation would be unstructured, adopting a clear structure only when complexed with specific interacting proteins (Wright and Dyson 1999). Indeed, in the absence of a binding partner, the p53 TAD regions are easily digested by proteases, suggesting a loosely folded conformation (Pavletich et al. 1993). The unstructured nature of TADs has been proposed to facilitate interactions with multiple different protein partners and to allow TADs to be targeted for posttranslational modification (PTM) by various enzymes (Oldfield et al. 2008). PTMs can promote or hinder p53 interactions with specific protein partners, thereby regulating p53 function (Meek and Anderson 2009; Teufel et al. 2009).

The structure of the p53 TADs was first solved in the context of an Mdm2-p53 complex by X-ray crystallography. Minimal regions of both Mdm2 and p53 TAD1 (amino acids 15-29) sufficient for interacting were cocrystalized (Kussie et al. 1996). Mdm2 was found to form a deep hydrophobic cleft into which the p53 peptide inserts as an amphipathic $\alpha$-helix. 
The Mdm2-p53 interaction is mediated by three highly conserved hydrophobic residues in human p53: F19, W23, and L26. Nuclear magnetic resonance (NMR) analyses of a p53 peptide comprising amino acids 17-24 also highlighted the critical role of residues F19 and W23 as well as L22 in the p53-MDM2 interaction (Blommers et al. 1997). As these p53 residues are important both for interactions with transcriptional machinery components and activating transcription, this study suggested further that p53 may bind transcriptional cofactors through an amphipathic $\alpha$-helical structure as well, which was subsequently borne out (see below). Collectively, these experiments provided the first information on p53 TAD structure.

The observation that p53 TADs are natively unfolded was confirmed by several studies of the structure of the p53 TADs in isolation. Circular dichroism and NMR analysis on full-length p53 as well as purified TADs in isolation (residues $1-93$ ) revealed that $\mathrm{p} 53$ TADs are largely devoid of secondary and tertiary structures under physiological conditions (Bell et al. 2002; Dawson et al. 2003; Wells et al. 2008). However, some NMR analyses of p53 residues 1-73 suggested that although the p53 TADs lack tertiary structure, they do contain some secondary structure, specifically an amphipathic $\alpha$-helix between T18 and L26 and two nascent amphipathic turns, between M40 and M44 (turn 1) and D48 and W53 (turn 2) (Botuyan et al. 1997; Lee et al. 2000). The significance of these elements is suggested by the known importance of these residues for TAD function. Moreover, the unbound TAD1 $\alpha$-helix resembles the Mdm2bound TAD1, suggesting that binding of p53 to targets simply tightens the $\alpha$-helix into a more stable form. Interestingly, subsequent NMR experiments showed that Mdm2 not only binds the $\alpha$-helix in TAD1 but also the turn regions in TAD2, which, on Mdm2 binding, form a fully stable TAD2 helix that inserts into the Mdm2 cleft, although with lower affinity than TAD1 (Chi et al. 2005; Shan et al. 2012).

Various subsequent studies examined p53 TAD1 or TAD2 complexed with other proteins, including MdmX, TFIIH, p300, and CBP
(Di Lello et al. 2006; Teufel et al. 2007; Popowicz et al. 2008; Feng et al. 2009; Lee et al. 2009, 2010a,b; Miller Jenkins et al. 2015). The crystal structure of the p53-binding domain of MdmX bound to p53 TAD1 residues 15-29 revealed that the p53 TAD1 hydrophobic residues F19, W23, and L26 form the primary contact surfaces for this interaction, as with the p53-Mdm2 interaction (Popowicz et al. 2008). The structure of p53 TAD2 complexed to the $\mathrm{PH}$ domain of yeast TFIIH (Tfbl) was solved by NMR (Di Lello et al. 2006), and although unstructured when unbound, p53 TAD2 residues 4755 form an amphipathic $\alpha$-helix on binding to Tfb1. Three hydrophobic residues (I50, W53, and F54) in this amphipathic $\alpha$-helix make crucial contacts with Tfbl, providing an explanation for any compromise in TAD2 transcriptional activity arising from mutations in these residues. Interestingly, NMR studies suggested that p53 TAD2 binds the human TFIIH subunit p62 through a different structure from Tfb1an extended string-like conformation rather than an amphipathic $\alpha$-helix (Okuda and Nishimura 2014). Considerable attention has also been focused on solving the structure of the p53 TADs in complex with the KIX, TAZ1/ $\mathrm{CH} 1, \mathrm{TAZ} 2 / \mathrm{CH} 3$, or NCBD domains of p300 and CBP. In one study, the NMR structure of the p300 TAZ2 domain and p53 TAD1 showed that p53 forms an $\alpha$-helix that interacts with TAZ2 via residues F19, L22, and L25 (Miller Jenkins et al. 2015). The NMR structure of the p300 TAZ2 domain complexed with p53 TAD2 residues 35-59 showed that TAD2 also forms an $\alpha$-helix that interacts with TAZ2 via I50, W53, and F54 (Feng et al. 2009). Similarly, the NMR structures of both p53 TADs with either the KIX or NCBD domain of CBP revealed that the two p53 TADs fold into a pair of helices (F19-L25 and P47-W53) on interacting with these CBP domains (Lee et al. 2009, 2010b). These studies collectively also highlighted how PTMs on p53 can enhance p53 interactions with p300/CBP, as discussed below.

An additional interesting structural aspect of p53 TADs came to light on characterizing their interaction with the single-stranded DNA (ssDNA)-binding proteins RPA (replica- 
tion protein A), PC4 (positive cofactor 4), and high mobility group B1 (HMGB1), proteins involved in transcription, DNA replication, DNA recombination, and DNA repair (Wold 1997; Bochkareva et al. 2005; Rowell et al. 2012; Mortusewicz et al. 2015). Initial biochemical studies showed that $\mathrm{p} 53$ TAD residues $1-73$ are sufficient for interaction with RPA (Dutta et al. 1993; He et al. 1993; Li and Botchan 1993). NMR analysis of the p53 TAD-RPA complex revealed that p53 TAD residues $47-57$ adopt an amphipathic $\alpha$-helical structure on interaction and that this interaction resembles that of RPA with ssDNA (Bochkareva et al. 2005). Specifically, in this complex, p53 residues I50 and F54 are reminiscent of the DNA bases while the side chain carbonyl groups mimic the phosphate backbone of DNA. Similarly, p53 TAD2 (residues 35-57) adopts an $\alpha$-helical conformation on interaction with PC4 in a manner reminiscent of the PC4-ssDNA interaction (Rajagopalan et al. 2009). These findings have advanced the model that p53 TADs mimic ssDNA structure, which may help recruit DNA metabolism factors that may facilitate PIC formation or liberate p53 from RPA at sites of DNA damage, where ssDNA accumulates. The NMR structure of the high mobility group B1 (HMGB1) protein A-box and p53 residues 1-93 also revealed that p53 TAD2 adopts an amphipathic $\alpha$-helical structure on binding to the A-box, again mimicking ssDNA, but in this case HMGB1 is proposed to facilitate $\mathrm{p} 53$ binding to DNA (Rowell et al. 2012).

\section{THE IMPACT OF p53 AMINO- TERMINAL PHOSPHORYLATION ON TRANSACTIVATION DOMAIN FUNCTION}

The studies of p53 TAD-interacting partners have provided great support for the idea that phosphorylation of p53 TADs plays a large part in regulating these interactions. Diverse kinases can phosphorylate the p53 TADs, including ATM, ATR, Chk2, MAPK, HIPK, and various CDKs (Jenkins et al. 2012). Phosphorylation of sites within the amino-terminal TADs (Fig. 1C) in response to DNA-damage signals not only relieves p53 from negative regulation by Mdm2 and MdmX but also facilitates transcriptional activity by enhancing binding to certain interacting partners, including TFIIH and CBP/p300 (Lambert et al. 1998; Sakaguchi et al. 2000; Schon et al. 2002; Di Lello et al. 2006; Polley et al. 2008; Ferreon et al. 2009; Jenkins et al. 2009, 2012). Numerous studies showed that phosphorylation of single or multiple p53 TAD residues including S15, T18, S20, S33, S37, S46, or T55 increases the binding affinity to individual domains of p300/CBP (Lambert et al. 1998; Polley et al. 2008; Feng et al. 2009; Ferreon et al. 2009; Jenkins et al. 2009, 2012; Teufel et al. 2009; Lee et al. 2010a). Interestingly, heptaphosphorylation of both TADs at S15, T18, S20, S33, S37, S46, and T55 induces 40fold and 80 -fold more binding of p53 to the TAZ1/CH1 and TAZ2/CH3 domains of p300, respectively (without effects on KIX or IBiD), as well as a 24-fold reduction of binding to Mdm2 (Teufel et al. 2009). These studies thus provide a mechanism for phosphorylation-mediated replacement of Mdm2 with p300 or CBP, thereby stabilizing p53 and enhancing p53 transactivation. Phosphorylation of either S46 or T55 in TAD2 also enhances p53 binding to p62 and Tfb1 subunits of TFIIH, suggesting another mechanism by which p53 phosphorylation enhances transcription (Di Lello et al. 2006). The significance of these interaction studies is borne out in numerous biological studies. For example, in microarray studies of cells expressing p53 with mutations in all serines of the TADs (S6, S9, S15, S20, S33, S37, S46), a significant decrease in the number of p53-induced genes is observed relative to cells expressing wild-type p53 (Ohki et al. 2007). Moreover, some studies in cultured cells and in knockin mice with mutations in specific phosphorylation sites support the importance of these phosphorylation sites for transactivation of p53 target genes and p53 biological function (Mayr et al. 1995; Lohrum and Scheidtmann 1996; Siliciano et al. 1997; Chao et al. 2003; Sluss et al. 2004). For example, cells from $p 53^{S 18 A / S 18 A}$ knockin mice show similar DNA-damage-induced p53 stabilization and DNA binding as cells expressing wild-type p53, but target gene activation and 
apoptosis are compromised (Chao et al. 2003; Sluss et al. 2004). Thus, PTM of the TADs provides an important mechanism for modulating p53 transcriptional activity.

\section{SUMMARY AND PERSPECTIVES}

Since the original description of p53 function as a transcriptional activator, many studies have delved into the intricacies of this function. Although many molecular details remain to be fully elucidated, the studies summarized here have illuminated how p53 transcriptional activation function contributes to its biological roles as well as the mechanisms through which p53 activates transcription. Analyses of p53 TAD mutant knockin mice have revealed the importance of p53 transactivation activity in various p53 biological functions, including DNA-damage responses, promoting developmental phenotypes, and tumor suppression. Interestingly, different TADs are required in different contexts, suggesting that different transcriptional networks are involved in diverse biological responses. Genomic studies will continually add to this picture by elaborating target genes involved in different p53 responses. As a transcription factor, p53 acts by stimulating chromatin remodeling and the recruitment of the transcription machinery to enhance transcriptional initiation and elongation of a host of genes. Biochemical and structural biological studies have revealed critical TAD-interacting partners through which p53 acts to enhance transcription. Future studies will not only continue to decipher the targets most central to different p53 responses, but also elucidate how the two TADs act mechanistically at different classes of genes and whether modulating TADs can be of any therapeutic benefit. Intriguingly, the role of TAD1 is most important for acute DNA-damage responses, but dispensable for tumor suppression, suggesting that its inhibition could help spare cancer patients some of the side effects of genotoxic cancer therapies. Further unraveling of the molecular underpinnings of p53 transcriptional activation will ultimately lead to improved cancer therapeutics.

\section{ACKNOWLEDGMENTS}

We thank Kathryn Bieging-Rolett, Stephano Spano Mello, and Patty Garcia for critical reading of the manuscript. We apologize to those whose work was not cited because of space constraints.

\section{REFERENCES}

An W, Kim J, Roeder RG. 2004. Ordered cooperative functions of PRMT1, p300, and CARM1 in transcriptional activation by p53. Cell 117: 735-748.

Attardi LD, Tjian R. 1993. Drosophila tissue-specific transcription factor NTF-1 contains a novel isoleucine-rich activation motif. Genes Dev 7: 1341-1353.

Attardi LD, Lowe SW, Brugarolas J, Jacks T. 1996. Transcriptional activation by $\mathrm{p} 53$, but not induction of the p 21 gene, is essential for oncogene-mediated apoptosis. EMBO J 15: 3693-3701.

Avantaggiati ML, Ogryzko V, Gardner K, Giordano A, Levine AS, Kelly K. 1997. Recruitment of p300/CBP in p53dependent signal pathways. Cell 89: 1175-1184.

Baptiste N, Friedlander P, Chen X, Prives C. 2002. The proline-rich domain of p53 is required for cooperation with anti-neoplastic agents to promote apoptosis of tumor cells. Oncogene 21: 9-21.

Baptiste-Okoh N, Barsotti AM, Prives C. 2008. A role for caspase 2 and PIDD in the process of p53-mediated apoptosis. Proc Natl Acad Sci 105: 1937-1942.

Bargonetti J, Friedman PN, Kern SE, Vogelstein B, Prives C. 1991. Wild-type but not mutant p53 immunopurified proteins bind to sequences adjacent to the SV40 origin of replication. Cell 65: 1083-1091.

Bargonetti J, Manfredi JJ, Chen X, Marshak DR, Prives C. 1993. A proteolytic fragment from the central region of p53 has marked sequence-specific DNA-binding activity when generated from wild-type but not from oncogenic mutant p53 protein. Genes Dev 7: 2565-2574.

Bell S, Klein C, Muller L, Hansen S, Buchner J. 2002. p53 contains large unstructured regions in its native state. $J$ Mol Biol 322: 917-927.

Bieging KT, Mello SS, Attardi LD. 2014. Unravelling mechanisms of p53-mediated tumour suppression. Nat Rev Cancer 14: 359-370.

Blommers MJJ, Fendrich G, Garcia-Echeverria C, Chene P. 1997. On the interaction between p53 and MDM2: Transfer NOE study of a p53-derived peptide ligated to MDM2. J Am Chem Soc 119: 3425-3426.

Bochkareva E, Kaustov L, Ayed A, Yi GS, Lu Y, PinedaLucena A, Liao JC, Okorokov AL, Milner J, Arrowsmith $\mathrm{CH}$, et al. 2005. Single-stranded DNA mimicry in the p53 transactivation domain interaction with replication protein A. Proc Natl Acad Sci 102: 15412-15417.

Botuyan MV, Momand J, Chen Y. 1997. Solution conformation of an essential region of the p53 transactivation domain. Fold Des 2: 331-342.

Brady CA, Jiang D, Mello SS, Johnson TM, Jarvis LA, Kozak MM, Kenzelmann Broz D, Basak S, Park EJ, McLaughlin 
ME, et al. 2011. Distinct p53 transcriptional programs dictate acute DNA-damage responses and tumor suppression. Cell 145: 571-583.

Brooks CL, Gu W. 2003. Ubiquitination, phosphorylation and acetylation: The molecular basis for p53 regulation. Curr Opin Cell Biol 15: 164-171.

Candau R, Scolnick DM, Darpino P, Ying CY, Halazonetis TD, Berger SL. 1997. Two tandem and independent subactivation domains in the amino terminus of $\mathrm{p} 53$ require the adaptor complex for activity. Oncogene 15: 807-816.

Chang J, Kim DH, Lee SW, Choi KY, Sung YC. 1995. Transactivation ability of p53 transcriptional activation domain is directly related to the binding affinity to TATAbinding protein. J Biol Chem 270: 25014-25019.

Chao C, Saito S, Kang J, Anderson CW, Appella E, Xu Y. 2000. p53 transcriptional activity is essential for p53-dependent apoptosis following DNA damage. EMBO J 19: 4967-4975.

Chao C, Hergenhahn M, Kaeser MD, Wu Z, Saito S, Iggo R, Hollstein M, Appella E, Xu Y. 2003. Cell type- and promoter-specific roles of Ser 18 phosphorylation in regulating p53 responses. J Biol Chem 278: 41028-41033.

Chen J, Marechal V, Levine AJ. 1993a. Mapping of the p53 and mdm-2 interaction domains. Mol Cell Biol 13: 41074114.

Chen X, Farmer G, Zhu H, Prywes R, Prives C. 1993b. Cooperative DNA binding of $\mathrm{p} 53$ with TFIID (TBP): A possible mechanism for transcriptional activation. Genes Dev 7: 1837-1849.

Chen X, Ko LJ, Jayaraman L, Prives C. 1996. p53 levels, functional domains, and DNA damage determine the extent of the apoptotic response of tumor cells. Genes Dev 10: $2438-2451$.

Chi SW, Lee SH, Kim DH, Ahn MJ, Kim JS, Woo JY, Torizawa T, Kainosho M, Han KH. 2005. Structural details on mdm2-p53 interaction. J Biol Chem 280: 38795-38802.

Conaway RC, Conaway JW. 1993. General initiation factors for RNA polymerase II. Annu Rev Biochem 62: 161-190.

Conaway RC, Conaway JW. 2013. The Mediator complex and transcription elongation. Biochim Biophys Acta 1829: $69-75$.

Cress WD, Triezenberg SJ. 1991. Critical structural elements of the VP16 transcriptional activation domain. Science 251: 87-90.

Dawson R, Muller L, Dehner A, Klein C, Kessler H, Buchner J. 2003. The N-terminal domain of p53 is natively unfolded. J Mol Biol 332: 1131-1141.

de Rozieres S, Maya R, Oren M, Lozano G. 2000. The loss of $\mathrm{mdm} 2$ induces p53-mediated apoptosis. Oncogene 19: 1691-1697.

Di Lello P, Jenkins LM, Jones TN, Nguyen BD, Hara T, Yamaguchi H, Dikeakos JD, Appella E, Legault P, Omichinski JG. 2006. Structure of the Tfb1/p53 complex: Insights into the interaction between the p62/Tfb1 subunit of TFIIH and the activation domain of p53. Mol Cell 22: 731-740.

Dippold WG, Jay G, DeLeo AB, Khoury G, Old LJ. 1981. p53 transformation-related protein: Detection by monoclonal antibody in mouse and human cells. Proc Natl Acad Sci 78: 1695-1699.
Drysdale CM, Duenas E, Jackson BM, Reusser U, Braus GH, Hinnebusch AG. 1995. The transcriptional activator GCN4 contains multiple activation domains that are critically dependent on hydrophobic amino acids. Mol Cell Biol 15: 1220-1233.

Dutta A, Ruppert JM, Aster JC, Winchester E. 1993. Inhibition of DNA replication factor RPA by p53. Nature 365: 79-82.

Farmer G, Bargonetti J, Zhu H, Friedman P, Prywes R, Prives C. 1992. Wild-type p53 activates transcription in vitro. Nature 358: 83-86.

Feng H, Jenkins LM, Durell SR, Hayashi R, Mazur SJ, Cherry S, Tropea JE, Miller M, Wlodawer A, Appella E, et al. 2009. Structural basis for p300 Taz2-p53 TAD1 binding and modulation by phosphorylation. Structure 17: 202210.

Ferreon JC, Lee CW, Arai M, Martinez-Yamout MA, Dyson HJ, Wright PE. 2009. Cooperative regulation of p53 by modulation of ternary complex formation with CBP/ p300 and HDM2. Proc Natl Acad Sci 106: 6591-6596.

Fields S, Jang SK. 1990. Presence of a potent transcription activating sequence in the p53 protein. Science 249: 1046-1049.

Finch RA, Donoviel DB, Potter D, Shi M, Fan A, Freed DD, Wang CY, Zambrowicz BP, Ramirez-Solis R, Sands AT, et al. 2002. $\mathrm{mdmx}$ is a negative regulator of p53 activity in vivo. Cancer Res 62: 3221-3225.

Gamper AM, Roeder RG. 2008. Multivalent binding of p53 to the STAGA complex mediates coactivator recruitment after UV damage. Mol Cell Biol 28: 2517-2527.

Geng F, Wenzel S, Tansey WP. 2012. Ubiquitin and proteasomes in transcription. Annu Rev Biochem 81: 177-201.

Gill G, Pascal E, Tseng ZH, Tjian R. 1994. A glutamine-rich hydrophobic patch in transcription factor $\mathrm{Sp} 1$ contacts the $\mathrm{dTAF}_{\mathrm{II}} 110$ component of the Drosophila TFIID complex and mediates transcriptional activation. Proc Natl Acad Sci 91: 192-196.

Gu W, Shi XL, Roeder RG. 1997. Synergistic activation of transcription by CBP and p53. Nature 387: 819-823.

Haupt Y, Rowan S, Shaulian E, Vousden KH, Oren M. 1995. Induction of apoptosis in HeLa cells by trans-activationdeficient p53. Genes Dev 9: 2170-2183.

Haupt Y, Maya R, Kazaz A, Oren M. 1997. Mdm2 promotes the rapid degradation of p53. Nature 387: 296-299.

He Z, Brinton BT, Greenblatt J, Hassell JA, Ingles CJ. 1993. The transactivator proteins VP16 and GAL4 bind replication factor A. Cell 73: 1223-1232.

Hollenberg SM, Evans RM. 1988. Multiple and cooperative trans-activation domains of the human glucocorticoid receptor. Cell 55: 899-906.

Honda R, Tanaka H, Yasuda H. 1997. Oncoprotein MDM2 is a ubiquitin ligase E3 for tumor suppressor p53. FEBS Lett 420: 25-27.

Horikoshi N, Usheva A, Chen J, Levine AJ, Weinmann R, Shenk T. 1995. Two domains of p53 interact with the TATA-binding protein, and the adenovirus $13 \mathrm{~S}$ E1A protein disrupts the association, relieving p53-mediated transcriptional repression. Mol Cell Biol 15: 227-234.

Hu B, Gilkes DM, Farooqi B, Sebti SM, Chen J. 2006. MDMX overexpression prevents p53 activation by the MDM2 inhibitor Nutlin. J Biol Chem 281: 33030-33035. 
Hulboy DL, Lozano G. 1994. Structural and functional analysis of p53: The acidic activation domain has transforming capability. Cell Growth Differ 5: 1023-1031.

Ito M, Yuan CX, Malik S, Gu W, Fondell JD, Yamamura S, Fu ZY, Zhang X, Qin J, Roeder RG. 1999. Identity between TRAP and SMCC complexes indicates novel pathways for the function of nuclear receptors and diverse mammalian activators. Mol Cell 3: 361-370.

Jenkins LM, Yamaguchi H, Hayashi R, Cherry S, Tropea JE, Miller M, Wlodawer A, Appella E, Mazur SJ. 2009. Two distinct motifs within the p53 transactivation domain bind to the Taz2 domain of p300 and are differentially affected by phosphorylation. Biochemistry 48: 12441255.

Jenkins LM, Durell SR, Mazur SJ, Appella E. 2012. p53 Nterminal phosphorylation: A defining layer of complex regulation. Carcinogenesis 33: 1441-1449.

Jiang D, Brady CA, Johnson TM, Lee EY, Park EJ, Scott MP, Attardi LD. 2011. Full p53 transcriptional activation potential is dispensable for tumor suppression in diverse lineages. Proc Natl Acad Sci 108: 17123-17128.

Jimenez GS, Nister M, Stommel JM, Beeche M, Barcarse EA, Zhang XQ, O'Gorman S, Wahl GM. 2000. A transactivation-deficient mouse model provides insights into Trp53 regulation and function. Nat Genet 26: 37-43.

Johnson TM, Hammond EM, Giaccia A, Attardi LD. 2005. The $\mathrm{p} 53^{\mathrm{QS}}$ transactivation-deficient mutant shows stressspecific apoptotic activity and induces embryonic lethality. Nat Genet 37: 145-152.

Johnson TM, Meade K, Pathak N, Marques MR, Attardi LD. 2008. Knockin mice expressing a chimeric p53 protein reveal mechanistic differences in how p53 triggers apoptosis and senescence. Proc Natl Acad Sci 105: 12151220.

Jones SN, Roe AE, Donehower LA, Bradley A. 1995. Rescue of embryonic lethality in Mdm2-deficient mice by absence of p53. Nature 378: 206-208.

Jongmans MC, Admiraal RJ, van der Donk KP, Vissers LE, Baas AF, Kapusta L, van Hagen JM, Donnai D, de Ravel TJ, Veltman JA, et al. 2006. CHARGE syndrome: The phenotypic spectrum of mutations in the CHD7 gene. J Med Genet 43: 306-314.

Kern SE, Kinzler KW, Bruskin A, Jarosz D, Friedman P, Prives C, Vogelstein B. 1991. Identification of p53 as a sequence-specific DNA-binding protein. Science 252: $1708-1711$.

Kim SY, Herbst A, Tworkowski KA, Salghetti SE, Tansey WP. 2003. Skp2 regulates Myc protein stability and activity. Mol Cell 11: 1177-1188.

Kobet E, Zeng X, Zhu Y, Keller D, Lu H. 2000. MDM2 inhibits pp300-mediated p53 acetylation and activation by forming a ternary complex with the two proteins. Proc Natl Acad Sci 97: 12547-12552.

Kokontis JM, Wagner AJ, O’Leary M, Liao S, Hay N. 2001. A transcriptional activation function of p53 is dispensable for and inhibitory of its apoptotic function. Oncogene 20: 659-668.

Kubbutat MH, Jones SN, Vousden KH. 1997. Regulation of p53 stability by Mdm2. Nature 387: 299-303.

Kussie PH, Gorina S, Marechal V, Elenbaas B, Moreau J, Levine AJ, Pavletich NP. 1996. Structure of the MDM2 oncoprotein bound to the $\mathrm{p} 53$ tumor suppressor transactivation domain. Science 274: 948-953.

Lambert PF, Kashanchi F, Radonovich MF, Shiekhattar R, Brady JN. 1998. Phosphorylation of p53 serine 15 increases interaction with CBP. J Biol Chem 273: 3304833053.

Lech K, Anderson K, Brent R. 1988. DNA-bound Fos proteins activate transcription in yeast. Cell 52: 179-184.

Lee H, Mok KH, Muhandiram R, Park KH, Suk JE, Kim DH, Chang J, Sung YC, Choi KY, Han KH. 2000. Local structural elements in the mostly unstructured transcriptional activation domain of human p53. J Biol Chem 275: 29426-29432.

Lee CW, Arai M, Martinez-Yamout MA, Dyson HJ, Wright PE. 2009. Mapping the interactions of the p53 transactivation domain with the KIX domain of CBP. Biochemistry 48: $2115-2124$.

Lee CW, Ferreon JC, Ferreon AC, Arai M, Wright PE. 2010a. Graded enhancement of p53 binding to CREB-binding protein (CBP) by multisite phosphorylation. Proc Natl Acad Sci 107: 19290-19295.

Lee CW, Martinez-Yamout MA, Dyson HJ, Wright PE. 2010b. Structure of the p53 transactivation domain in complex with the nuclear receptor coactivator binding domain of CREB binding protein. Biochemistry 49: 9964-9971.

Lemon B, Tjian R. 2000. Orchestrated response: A symphony of transcription factors for gene control. Genes Dev 14: 2551-2569.

Levine AJ, Finlay CA, Hinds PW. 2004. P53 is a tumor suppressor gene. Cell 116: S67-S70.

Li R, Botchan MR. 1993. The acidic transcriptional activation domains of VP16 and p53 bind the cellular replication protein A and stimulate in vitro BPV-1 DNA replication. Cell 73: 1207-1221.

Li M, Luo J, Brooks CL, Gu W. 2002. Acetylation of p53 inhibits its ubiquitination by Mdm2. J Biol Chem 277: 50607-50611.

Lill NL, Grossman SR, Ginsberg D, DeCaprio J, Livingston DM. 1997. Binding and modulation of $\mathrm{p} 53$ by $\mathrm{p} 300 / \mathrm{CBP}$ coactivators. Nature 387: 823-827.

Lin J, Chen J, Elenbaas B, Levine AJ. 1994. Several hydrophobic amino acids in the $\mathrm{p} 53$ amino-terminal domain are required for transcriptional activation, binding to $\mathrm{mdm}-2$ and the adenovirus $5 \mathrm{E} 1 \mathrm{~B} 55-\mathrm{kD}$ protein. Genes Dev 8: $1235-1246$.

Lipford JR, Deshaies RJ. 2003. Diverse roles for ubiquitindependent proteolysis in transcriptional activation. Nat Cell Biol 5: 845-850.

Liu X, Miller CW, Koeffler PH, Berk AJ. 1993. The p53 activation domain binds the TATA box-binding polypeptide in Holo-TFIID, and a neighboring p53 domain inhibits transcription. Mol Cell Biol 13: 3291-3300.

Lohrum M, Scheidtmann KH. 1996. Differential effects of phosphorylation of rat $\mathrm{p} 53$ on transactivation of promoters derived from different p53 responsive genes. Oncogene 13: 2527-2539.

Lu H, Levine AJ. 1995. Human $\operatorname{TAF}_{\text {II }} 31$ protein is a transcriptional coactivator of the $\mathrm{p} 53$ protein. Proc Natl Acad Sci 92: 5154-5158. 
Ma J, Ptashne M. 1987. Deletion analysis of GAL4 defines two transcriptional activating segments. Cell 48: 847853.

Mayr GA, Reed M, Wang P, Wang Y, Schweds JF, Tegtmeyer P. 1995. Serine phosphorylation in the NH2 terminus of p53 facilitates transactivation. Cancer Res 55: 2410-2417.

Meek DW, Anderson CW. 2009. Posttranslational modification of p53: Cooperative integrators of function. Cold Spring Harb Perspect Biol 1: a000950.

Mermod N, O'Neill EA, Kelly TJ, Tjian R. 1989. The prolinerich transcriptional activator of CTF/NF-I is distinct from the replication and DNA binding domain. Cell 58: 741-753.

Meyer KD, Lin SC, Bernecky C, Gao Y, Taatjes DJ. 2010. p53 activates transcription by directing structural shifts in Mediator. Nat Struct Mol Biol 17: 753-760.

Migliorini D, Lazzerini Denchi E, Danovi D, Jochemsen A Capillo M, Gobbi A, Helin K, Pelicci PG, Marine JC. 2002. Mdm4 (Mdmx) regulates p53-induced growth arrest and neuronal cell death during early embryonic mouse development. Mol Cell Biol 22: 5527-5538.

Miller Jenkins LM, Feng H, Durell SR, Tagad HD, Mazur SJ, Tropea JE, Bai Y, Appella E. 2015. Characterization of the p300 Taz2-p53 TAD2 complex and comparison with the p300 Taz2-p53 TAD1 complex. Biochemistry 54: 2001 2010.

Momand J, Zambetti GP, Olson DC, George D, Levine AJ. 1992. The $m d m-2$ oncogene product forms a complex with the p53 protein and inhibits p53-mediated transactivation. Cell 69: 1237-1245.

Montes de Oca Luna R, Wagner DS, Lozano G. 1995. Rescue of early embryonic lethality in $m d m 2$-deficient mice by deletion of p53. Nature 378: 203-206.

Mortusewicz O, Evers B, Helleday T. 2015. PC4 promotes genome stability and DNA repair through binding of ssDNA at DNA damage sites. Oncogene doi: 10.1038/ onc.2015.135.

Murakami K, Elmlund H, Kalisman N, Bushnell DA, Adams CM, Azubel M, Elmlund D, Levi-Kalisman Y, Liu X, Gibbons BJ, et al. 2013. Architecture of an RNA polymerase II transcription pre-initiation complex. Science 342: 1238724.

Muratani M, Tansey WP. 2003. How the ubiquitin-proteasome system controls transcription. Nat Rev Mol Cell Biol 4: 192-201.

Nister M, Tang M, Zhang XQ, Yin C, Beeche M, Hu X, Enblad G, van Dyke T, Wahl GM. 2005. p53 must be competent for transcriptional regulation to suppress tumor formation. Oncogene 24: 3563-3573.

Ohki R, Kawase T, Ohta T, Ichikawa H, Taya Y. 2007. Dissecting functional roles of p53 N-terminal transactivation domains by microarray expression analysis. Cancer Sci 98: 189-200.

Okuda M, Nishimura Y. 2014. Extended string binding mode of the phosphorylated transactivation domain of tumor suppressor p53. J Am Chem Soc 136: 1414314152.

Oldfield CJ, Meng J, Yang JY, Yang MQ, Uversky VN, Dunker AK. 2008. Flexible nets: Disorder and induced fit in the associations of p53 and 14-3-3 with their partners. BMC Genom 9: S1.
Oliner JD, Kinzler KW, Meltzer PS, George DL, Vogelstein B. 1992. Amplification of a gene encoding a p53-associated protein in human sarcomas. Nature 358: 80-83.

O'Rourke RW, Miller CW, Kato GJ, Simon KJ, Chen DL, Dang CV, Koeffler HP. 1990. A potential transcriptional activation element in the p53 protein. Oncogene 5: 18291832.

Parant J, Chavez-Reyes A, Little NA, Yan W, Reinke V, Jochemsen AG, Lozano G. 2001. Rescue of embryonic lethality in Mdm4-null mice by loss of Trp53 suggests a nonoverlapping pathway with MDM2 to regulate p53. Nat Genet 29: 92-95.

Pavletich NP, Chambers KA, Pabo CO. 1993. The DNAbinding domain of p53 contains the four conserved regions and the major mutation hot spots. Genes Dev 7: 2556-2564.

Pennica D, Goeddel DV, Hayflick JS, Reich NC, Anderson CW, Levine AJ. 1984. The amino acid sequence of murine p53 determined from a c-DNA clone. Virology 134: 477482.

Pietenpol JA, Tokino T, Thiagalingam S, el-Deiry WS, Kinzler KW, Vogelstein B. 1994. Sequence-specific transcriptional activation is essential for growth suppression by p53. Proc Natl Acad Sci 91: 1998-2002.

Polley S, Guha S, Roy NS, Kar S, Sakaguchi K, Chuman Y, Swaminathan V, Kundu T, Roy S. 2008. Differential recognition of phosphorylated transactivation domains of p53 by different p300 domains. J Mol Biol 376: 8-12.

Popowicz GM, Czarna A, Holak TA. 2008. Structure of the human Mdmx protein bound to the p53 tumor suppressor transactivation domain. Cell Cycle 7: 2441-2443.

Rajagopalan S, Andreeva A, Teufel DP, Freund SM, Fersht AR. 2009. Interaction between the transactivation domain of p53 and PC4 exemplifies acidic activation domains as single-stranded DNA mimics. J Biol Chem 284: 21728-21737.

Raycroft L, Wu HY, Lozano G. 1990. Transcriptional activation by wild-type but not transforming mutants of the p53 anti-oncogene. Science 249: 1049-1051.

Raycroft L, Schmidt JR, Yoas K, Hao MM, Lozano G. 1991. Analysis of p53 mutants for transcriptional activity. Mol Cell Biol 11: 6067-6074.

Reed M, Wang Y, Mayr G, Anderson ME, Schwedes JF, Tegtmeyer P. 1993. p53 domains: Suppression, transformation, and transactivation. Gene Expr 3: 95-107.

Regier JL, Shen F, Triezenberg SJ. 1993. Pattern of aromatic and hydrophobic amino acids critical for one of two subdomains of the VP16 transcriptional activator. Proc Natl Acad Sci 90: 883-887.

Rodriguez MS, Desterro JM, Lain S, Lane DP, Hay RT. 2000. Multiple C-terminal lysine residues target p53 for ubiquitin-proteasome-mediated degradation. Mol Cell Biol 20: $8458-8467$.

Rowell JP, Simpson KL, Stott K, Watson M, Thomas JO. 2012. HMGB1-facilitated p53 DNA binding occurs via HMG-Box/p53 transactivation domain interaction, regulated by the acidic tail. Structure 20: 2014-2024.

Sabbatini P, McCormick F. 2002. MDMX inhibits the pp300/CBP-mediated acetylation of p53. DNA Cell Biol 21: 519-525. 
Sabbatini P, Lin J, Levine AJ, White E. 1995. Essential role for p53-mediated transcription in E1A-induced apoptosis. Genes Dev 9: 2184-2192.

Sakaguchi K, Saito S, Higashimoto Y, Roy S, Anderson CW, Appella E. 2000. Damage-mediated phosphorylation of human $\mathrm{p} 53$ threonine 18 through a cascade mediated by a casein 1-like kinase. Effect on Mdm2 binding. J Bio Chem 275: 9278-9283.

Salghetti SE, Muratani M, Wijnen H, Futcher B, Tansey WP. 2000. Functional overlap of sequences that activate transcription and signal ubiquitin-mediated proteolysis. Proc Natl Acad Sci 97: 3118-3123.

Salghetti SE, Caudy AA, Chenoweth JG, Tansey WP. 2001. Regulation of transcriptional activation domain function by ubiquitin. Science 293: 1651-1653.

Schon O, Friedler A, Bycroft M, Freund SM, Fersht AR. 2002. Molecular mechanism of the interaction between MDM2 and p53. J Mol Biol 323: 491-501.

Scolnick DM, Chehab NH, Stavridi ES, Lien MC, Caruso L, Moran E, Berger SL, Halazonetis TD. 1997. CREBbinding protein and p300/CBP-associated factor are transcriptional coactivators of the p53 tumor suppressor protein. Cancer Res 57: 3693-3696.

Seto E, Usheva A, Zambetti GP, Momand J, Horikoshi N, Weinmann R, Levine AJ, Shenk T. 1992. Wild-type p53 binds to the TATA-binding protein and represses transcription. Proc Natl Acad Sci 89: 12028-12032.

Shan B, Li DW, Bruschweiler-Li L, Bruschweiler R. 2012. Competitive binding between dynamic p53 transactivation subdomains to human MDM2 protein: Implications for regulating the p53 MDM2/MDMX interaction. J Biol Chem 287: 30376-30384.

Shvarts A, Steegenga WT, Riteco N, van Laar T, Dekker P, Bazuine M, van Ham RC, van der Houven van Oordt W, Hateboer G, van der Eb AJ, et al. 1996. MDMX: A novel p53-binding protein with some functional properties of MDM2. EMBO J 15: 5349-5357.

Siliciano JD, Canman CE, Taya Y, Sakaguchi K, Appella E, Kastan MB. 1997. DNA damage induces phosphorylation of the amino terminus of p53. Genes Dev 11: 3471-3481.

Sluss HK, Armata H, Gallant J, Jones SN. 2004. Phosphorylation of serine 18 regulates distinct p53 functions in mice. Mol Cell Biol 24: 976-984.

Soussi T, May P. 1996. Structural aspects of the $\mathrm{p} 53$ protein in relation to gene evolution: A second look. J Mol Biol 260: 623-637.

Teufel DP, Freund SM, Bycroft M, Fersht AR. 2007. Four domains of p300 each bind tightly to a sequence spanning both transactivation subdomains of p53. Proc Natl Acad Sci 104: 7009-7014.

Teufel DP, Bycroft M, Fersht AR. 2009. Regulation by phosphorylation of the relative affinities of the N-terminal transactivation domains of p53 for p300 domains and Mdm2. Oncogene 28: 2112-2118.
Thut CJ, Chen JL, Klemm R, Tjian R. 1995. p53 transcriptional activation mediated by coactivators $\mathrm{TAF}_{\mathrm{II}} 40$ and $\mathrm{TAF}_{\mathrm{II}}$ 60. Science 267: 100-104.

Truant R, Xiao H, Ingles CJ, Greenblatt J. 1993. Direct interaction between the transcriptional activation domain of human p53 and the TATA box-binding protein. J Biol Chem 268: 2284-2287.

Unger T, Nau MM, Segal S, Minna JD. 1992. p53: A transdominant regulator of transcription whose function is ablated by mutations occurring in human cancer. EMBO J 11: 1383-1390.

Van Nostrand JL, Brady CA, Jung H, Fuentes DR, Kozak MM, Johnson TM, Lin CY, Lin CJ, Swiderski DL, Vogel $\mathrm{H}$, et al. 2014. Inappropriate p53 activation during development induces features of CHARGE syndrome. $\mathrm{Na}$ ture 514: $228-232$.

Venot C, Maratrat M, Sierra V, Conseiller E, Debussche L. 1999. Definition of a p53 transactivation function-deficient mutant and characterization of two independent p53 transactivation subdomains. Oncogene 18: 24052410.

Vousden KH, Prives C. 2009. Blinded by the light: The growing complexity of p53. Cell 137: 413-431.

Walker KK, Levine AJ. 1996. Identification of a novel p53 functional domain that is necessary for efficient growth suppression. Proc Natl Acad Sci 93: 15335-15340.

Wells M, Tidow H, Rutherford TJ, Markwick P, Jensen MR, Mylonas E, Svergun DI, Blackledge M, Fersht AR. 2008. Structure of tumor suppressor p53 and its intrinsically disordered N-terminal transactivation domain. Proc Natl Acad Sci 105: 5762-5767.

Wold MS. 1997. Replication protein A: A heterotrimeric, single-stranded DNA-binding protein required for eukaryotic DNA metabolism. Annu Rev Biochem 66: 61-92.

Wright PE, Dyson HJ. 1999. Intrinsically unstructured proteins: Re-assessing the protein structure-function paradigm. J Mol Biol 293: 321-331.

Xiao H, Pearson A, Coulombe B, Truant R, Zhang S, Regier JL, Triezenberg SJ, Reinberg D, Flores O, Ingles CJ, et al. 1994. Binding of basal transcription factor TFIIH to the acidic activation domains of VP16 and p53. Mol Cell Biol 14: 7013-7024.

Zambetti GP, Bargonetti J, Walker K, Prives C, Levine AJ. 1992. Wild-type $\mathrm{p} 53$ mediates positive regulation of gene expression through a specific DNA sequence element. Genes Dev 6: 1143-1152.

Zhu J, Zhou W, Jiang J, Chen X. 1998. Identification of a novel p53 functional domain that is necessary for mediating apoptosis. J Biol Chem 273: 13030-13036.

Zhu J, Zhang S, Jiang J, Chen X. 2000. Definition of the p53 functional domains necessary for inducing apoptosis. $J$ Biol Chem 275: 39927-39934.

Zhu Q, Wani G, Yao J, Patnaik S, Wang QE, El-Mahdy MA, Praetorius-Ibba M, Wani AA. 2007. The ubiquitin-proteasome system regulates p53-mediated transcription at p21waf1 promoter. Oncogene 26: 4199-4208. 


\section{$\&_{\mathrm{CSH}}^{\infty} \&$ Cold Spring Harbor

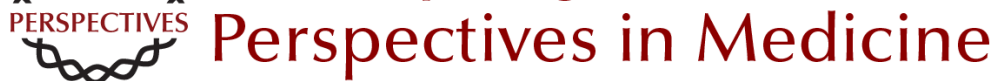

\section{The Transactivation Domains of the p53 Protein}

Nitin Raj and Laura D. Attardi

Cold Spring Harb Perspect Med 2017; doi: 10.1101/cshperspect.a026047 originally published online November 18, 2016

\section{Subject Collection The p53 Protein}

Targeting the MDM2-p53 Protein-Protein Interaction for New Cancer Therapy: Progress and Challenges

Shaomeng Wang, Yujun Zhao, Angelo Aguilar, et al.

Structural Evolution and Dynamics of the p53

Proteins

Giovanni Chillemi, Sebastian Kehrloesser,

Francesca Bernassola, et al.

Exploiting the p53 Pathway for Therapy Chit Fang Cheok and David Philip Lane

The Regulation of Cellular Functions by the p53 Protein: Cellular Senescence

Crystal A. Tonnessen-Murray, Guillermina Lozano and James G. Jackson

The Transactivation Domains of the p53 Protein Nitin Raj and Laura D. Attardi

The Evolution of the Ribosomal Protein-MDM2p53 Pathway

Chad Deisenroth, Derek A. Franklin and Yanping Zhang

Somatic TP53 Mutations in the Era of Genome

Sequencing

Pierre Hainaut and Gerd P. Pfeifer

The Paradox of p53: What, How, and Why? Yael Aylon and Moshe Oren
Control of Cellular Aging, Tissue Function, and Cancer by p53 Downstream of Telomeres Caitlin M. Roake and Steven E. Artandi

Inherited TP53 Mutations and the Li -Fraumeni Syndrome

Tanya Guha and David Malkin

TP53 Mutations in Hypodiploid Acute Lymphoblastic Leukemia

Evan Q. Comeaux and Charles G. Mullighan

Transcriptional Regulation by Wild-Type and

Cancer-Related Mutant Forms of p53

Neil T. Pfister and Carol Prives

The Inherited p53 Mutation in the Brazilian Population

Maria Isabel Achatz and Gerard P. Zambetti

TP53 Mutations in Breast and Ovarian Cancer Laxmi Silwal-Pandit, Anita Langerød and Anne-Lise Børresen-Dale

p53 and the Carcinogenicity of Chronic Inflammation

Andrei V. Gudkov and Elena A. Komarova

Oncogenic Mutant p53 Gain of Function

Nourishes the Vicious Cycle of Tumor

Development and Cancer Stem-Cell Formation

Yoav Shetzer, Alina Molchadsky and Varda Rotter

For additional articles in this collection, see http://perspectivesinmedicine.cshlp.org/cgi/collection/ 